\title{
Bodily Passions: Physiognomy and Drama in Giovan Battista Della Porta*
}

\author{
EUGENIO REFINI \\ Johns Hopkins University
}

This article explores the intersections of physiognomic knowledge and drama in the works of Neapolitan naturalist and playwright Giovan Battista Della Porta (1535-1616). It first looks at references to theatre-classical drama in particular-in Della Porta's writings on physiognomy, thus showing that Latin comic plays provided the naturalist with a gallery of stock characters able to summarize the alleged interdependence of physical and moral traits. The article then analyzes the various ways in which Della Porta-who was a prolific author of comedies-brought his physiognomic expertise into his own experience as a playwright. The study of these two different perspectives on the relation between physiognomy and drama reveals that, far from being a direct translation of physiognomic theories, Della Porta's dramatic production deploys an ironic and almost paradoxical take on physiognomy that aims to challenge (if not actually subvert) the very principles of the discipline.

Cet article explore les interactions entre la physionomie et le drame dans les ouvres du naturaliste et dramaturge napolitain Giovan Battista Della Porta (1535-1616). On examine d'abord les références que fait Della Porta au théâtre - en particulier à la tragédie classique - dans ses écrits sur la physionomie, avant de montrer que le théâtre comique latin a fourni au naturaliste une panoplie de personnages stéréotypés lui permettant de mettre en avant l'interdépendance présumée entre traits physiques et traits moraux. L'article poursuit en analysant les diverses façons dont Della Porta, auteur prolifique de comédies, a exploité dans son travail ses connaissances en physionomie et son expérience de dramaturge. L'étude de ces deux aspects de la relation entre physionomie et théâtre montre que l'œuvre dramatique de Della Porta déploie une approche ironique et presque paradoxale de la physionomie qui, bien loin d'être une traduction littérale des théories physionomiques, vise à remettre en question, voire à inverser, les principes fondamentaux de cette discipline.

\section{Nagician, scientist, alchemist: the intellectual profile of Neapolitan 1 naturalist and playwright Giovan Battista Della Porta (1535-1616), whom Jean Bodin charged with witchcraft in his De magorum daemonomania}

\footnotetext{
* I wish to thank the editors of this issue for their invaluable feedback on this article. Also, I wish to thank Lina Bolzoni, who first introduced me to Giovan Battista Della Porta, for the many inspiring conversations we had on this topic.
} 
(1591), is indeed most difficult to pin down. ${ }^{1}$ Witness to a turning point that proved crucial to the development of what we now call the scientific revolution, Della Porta did not adopt the far-reaching orderliness that informed the experience of the younger Galileo Galilei. Although profoundly concerned with the study of nature, the Neapolitan-whose scientific outcomes included the invention of the telescope-was still imbued with a culture in which the boundaries between magic and science were extremely blurred. His approach to nature, despite its encyclopedic breadth, was not based on the systematic method on which modern science was being built at the time. Yet Della Porta shared the idea of a critical relation to the auctoritates and their departures from direct observation of natural phenomena (which of course-when devoid of systematic enquiry-does not guarantee the correctness of new interpretations). In his treatise Magia naturalis, for instance, it is not rare to find several passages where the illustration of an argument is supported by allegedly empirical demonstrations. ${ }^{2}$

A similar concern with the autoptic study of nature informs many other works by Della Porta, particularly those devoted to human physiognomy, a field that made him famous throughout Europe. His complex reflection on the ways in which bodily signs ("i segni che sono fissi nel corpo") are supposed to reveal the natural inclination of men, as well as Della Porta's concern with the study of the physical manifestation of inner affections ("[gli] accidenti che trasmutano i segni"), is in fact informed by the controversial attempt to explore the human soul ("i costumi naturali dell'animo") through the analysis of the body: "Il nome della Fisonomia vien da physin, che vuol dir 'natura', e gnome, 'regola'; quasi volesse dir legge o regola di Natura che con certa regola, norma et ordine di natura si conosce da tal forma di corpo, si conosce tal passion

1. For Della Porta’s biography, see Giovanna Romei and Raffaella Zaccaria, "Della Porta, Giovambattista," Dizionario biografico degli italiani 37 (1989): 171-82. For an introduction to the multifaceted production of the author, see Paolo Piccari, Giovan Battista Della Porta: il filosofo, il retore, lo scienziato (Milan: Franco Angeli, 2007); Marco Santoro, ed., La "mirabile natura": scienza e magia in Giovan Battista Della Porta (Pisa: Fabrizio Serra Editore, 2016); Maurizio Torrini, ed., Giovan Battista Della Porta nell'Europa del suo tempo (Naples: Guida, 1986).

2. An introduction to the many facets of the Magia Naturalis is offered by Laura Balbiani, La Magia naturalis di Giovan Battista Della Porta: lingua, cultura e scienza in Europa all'inizio dell'età moderna (Bern and New York: Lang, 2001). 
dell'anima."3 Interestingly enough, within a very large corpus of works including disciplines as diverse as natural magic, art of memory, optics, agronomy, and military art, Della Porta's fascination with the ambiguities that characterize the relation between soul and body found a most productive test bed in drama, particularly in the rhetorical construction of dramatic characters. In fact, the natural philosopher was also the author of several plays that, in various ways, transposed onto the theatrical stage some of the assumptions informing Della Porta's reflection on physiognomy. Far from being a straightforward translation into drama, the relevance of Della Porta's physiognomical thought to his theatrical poetics is characterized by both analogies and significant differences. More precisely, as we shall see, while the plays do appropriate physiognomical tropes, they also challenge and, eventually, ironically overturn the intellectual frame of Della Porta's physiognomy. After focusing on the ways in which literature and drama are used by the author in his physiognomical discourse, this article will explore the response of drama itself to physiognomy so as to show that theatre proves the ideal space for both disclosing and questioning the many ambiguities entailed by the discipline.

\section{Physiognomy and drama}

As recalled above, Della Porta was widely known throughout Europe for his works on natural philosophy, particularly his successful Magia naturalis and various treatises on physiognomy such as De humana physiognomonia and Coelestis physiognomonia, which first appeared in Latin and were soon

3. Giovan Battista Della Porta, Della fisionomia dell'uomo libri sei, ed. Alfonso Paolella (Naples: Edizioni Scientifiche Italiane, 2013), 96; “The term physiognomy comes from physin, which means 'nature,' and gnome, which means 'rule,' as if it meant law or rule of Nature that, thanks to some norms and natural order, is knowable based on the shape of the body, from which it is also possible to know the nature of the soul." (All English translations of Italian and Latin sources are mine.) In the early modern period, physiognomy was per se considered a controversial discipline, especially when explicitly concerned with predicting people's behaviour through the signs of their body (which made it dangerously close to judiciary astrology). Della Porta, who had to face an inquisitorial trial, knew this too well, as suggested by his precautionary statements on the conjectural nature of his arguments. See Giovanni Aquilecchia, “Appunti su Giovan Battista Della Porta e l'Inquisizione," Studi secenteschi 9 (1968): 1-31; Oreste Trabucco, "Il corpus fisiognomico dellaportiano tra censura e autocensura," Atti del convegno dei Lincei 215 (2005): 235-72, 248-49. 
translated into Italian and other European languages. ${ }^{4}$ The Neapolitan, though, earned some reputation for his theatrical works as well. ${ }^{5}$ Usually discussed as minor products of his spare time, Della Porta's plays did have an impact on seventeenth-century drama, not only in Italy but also beyond the Alps. ${ }^{6}$ Consisting of fourteen comedies, one tragicomedy, one tragedy, and one sacred drama, Della Porta's is one of the most remarkable single-authored dramatic corpuses of the late Renaissance in terms of both numbers and literary quality. ${ }^{7}$ Given that (according to Della Porta's early biographers) other plays were lost, the Neapolitan's commitment as a playwright cannot be reduced to a minor component of his overall production. However, despite a certain amount of attention given by scholars to the author as a dramatist, what is still inadequately pursued is the attempt to look at the two sides of the author's production as parts of the same intellectual profile. ${ }^{8}$ Without ignoring the specificity of different genres, it is undeniable that rigid distinctions between intellectual fields-so

4. The first edition of Della Porta's Magia naturalis appeared in 1558, while the first Italian version of the text (Della magia naturale) was printed in 1560. De humana physiognomonia and Coelestis physiognomonia were published respectively in 1586 (in four books; a six-book version appeared in 1599) and 1603; Italian translations followed in 1598 (a four-book version; a translation of the six-book version appeared in 1610) and 1614. For a detailed list of editions of works by Della Porta, see Antonella Orlandi, Le edizioni dell'opera di Giovan Battista Della Porta (Pisa: Fabrizio Serra Editore, 2013); and, more specifically, Giovan Battista Della Porta, Coelestis physiognomonia, ed. Alfonso Paolella (Naples: Edizioni Scientifiche Italiane, 1996), xi-xxxii; Giovan Battista Della Porta, De humana physiognomonia libri sex, ed. Alfonso Paolella (Naples: Edizioni Scientifiche Italiane, 2011), xi-lxxxviii.

5. Important contribitions to the study of Della Porta's dramatic works are Louise George Clubb, Giambattista della Porta, Dramatist (Princeton: Princeton University Press, 1965); Raffaele Sirri, L'attività teatrale di Giovan Battista Della Porta (Naples: De Simone, 1968), and Sul teatro del Cinquecento (Naples: Morano Editore, 1989). See also the contributions on drama in the multi-authored volumes edited by Santoro and Torrini (see n1 for full reference). For an extensive bibliography on Della Porta's theatre, see Giovan Battista Della Porta, Teatro, ed. Raffaele Sirri (Naples: Edizioni Scientifiche Italiane, 4 vols., 2000-03), 1:ix-xxv.

6. See, for instance, Jean de Rotrou's comedy La soeur, based on Della Porta's La sorella, discussed in Francesco Orlando, Rotrou: dalla tragicommedia alla tragedia (Turin: Bottega d'Erasmo, 1963).

7. Della Porta's extant plays, all published between 1589 and 1616, have been republished in critical editions as part of the Edizione nazionale delle opera di Giovan Battista Della Porta: see Della Porta, Teatro.

8. Notable exceptions are two articles by Lina Bolzoni, “Teatro, pittura e fisiognomica nell'arte della memoria di Giovan Battista Della Porta," Intersezioni 8.3 (1988): 477-509, and "Retorica, teatro, iconologia nell'arte della memoria del Della Porta," in Torrini, ed., 337-86. 
typical of modern thought-were foreign to Renaissance culture. A passage from the editor's preface to Della Porta's last comedy, La Tabernaria (1616), published one year after the author's death, is emblematic of the way in which the multifaceted profile of the Neapolitan was perceived by his contemporaries:

Il Sig. Gio[van] Battista della Porta Napolitano, è stato Filosofo sì grande, e celebrato universalmente nelle scienze Matematiche, e Naturali, che non fa bisogno, ch'io mi sforzi a persuaderlo altrui, mentre con mille, e mille lingue, parlano delle sue alte virtù i tanti suoi dottissimi volumi. Questo per sollevarsi alle volte da i suoi più gravi componimenti, si ritirava nei giorni più caldi, e più noiosi dell'Estate in una sua amenissima Villa, dove perché egli non sapeva viver nell'otio, si tratteneva spiegando i suoi morali pensieri co 'l rappresentare ne' componimenti Comici, e Tragici l'intricate attioni dell'humana vita, con tanta facilità, e felicità d'ingegno, che ben si vede in queste sue ricreationi ancora quanto si estendesse il suo valore; come ci ne dan segno manifesto le sue bellissime Commedie, e Tragedie, che sono alle Stampe, piene di sentenze, di concetti mirabili, di motti argutissimi, e di pellegrine inventioni. ${ }^{9}$

In spite of the otium commonplace, which inevitably labels drama as a form of entertainment confined to the scientist's time off, the passage stresses the ethical weight of theatre within Della Porta's career. The combination of various forms of knowledge-all of which were granted epistemological value-was obviously not a problem for the author of the preface, and the familiarity with code switching described in this passage invites us to rethink critically the relation of the scientist to the man of letters. To this purpose, the interaction of

9. Della Porta, Teatro, 4, 269-70; "The Neapolitan Giovan Battista Della Porta was an acclaimed philosopher, universally celebrated for his expertise in mathematical and natural sciences. I do not need to convince my audience of this, for his own works speak about his high virtues. In order to take some rest from his serious commitments, Della Porta used to spend the warmest days of the summer in a beautiful villa of his. Since he did not like to waste time in idleness, he entertained himself and his friends illustrating his moral thoughts by representing in comedies and tragedies the intricate plots of human life; and he did so with such an ease and lively spirit that his value can be seen in those works as well. In fact, his beautiful comedies and tragedies, which were printed, are rich in remarkable conceits, mottos, and pleasant inventions." 
physiognomy and drama provides us with a most interesting set of questions to address.

First of all, it is worth recalling that literature in the broad sense of the term is crucial to Della Porta's physiognomical writings, where the author often refers to literary sources to confirm his theoretical statements. This strategy stands out at the very beginning of the treatise Della fisionomia dell'uomo, as suggested by the opening reflection about the conflict between the widespread practice of simulation and the need for intellectual tools able to grasp people's real intentions (a topic that, deeply rooted in the classical tradition, had been at the core of any physiognomical discourse since the pseudo-Aristotelian Physiognomy, and that had been revived by the early modern reflection on the examination of men's wits).$^{10}$ Cicero, Seneca, and Socrates are singled out by Della Porta as the authoritative voices on the matter. Their remarks about human nature are used to legitimize physiognomy as the only art able to penetrate the minds of men through their bodily signs:

L’animo umano, dice Cicerone, è così involto negli oscurissimi veli e così nascosto sotto la tenebrosa caligine della simulazione, che quando stimi gli occhi, la fronte e tutto il sembiante ti manifestino la verità e il parlar più di tutti, allor mentiscono più che mai. Si scorge talvolta, sotto sembianza di uomo benigno, come afferma Seneca, come animo di fera, anzi più fiero delle fiere fere. Per questo desiderò sommamente Socrate, accioché giamai no s'avesse ad ingannar uomo, che fusse una fenestra nel petto: che così non potrebbe star nascosto un cor doppio, ma a ciascun fusse lecito scoprir le volontà, i pensieri, le verità e le bugie. A questo così gran male, a così giusto desio di Socrate, ecco sodisfa a pieno la Fisonomia [...] Questa, dunque, da' segni che da lungi si scuoprono nell'uomo, così scopre i consigli et i costumi fuori, che par che penetri nei più occulti e più reposti luoghi del cuore, donata dalla somma clemenza di Dio per un singolar presente, accioché ciascuno, da manifesti segni ammonito, sappia che elegger o fuggir debba. ${ }^{11}$

10. In the wide bibliography on the topic, we should at least recall the seminal role played by Juan Huarte's Examen de ingenious para la sciencias (Baeza: Juan Bautista de Montoya, 1575).

11. Della Porta, Della fisionomia dell'uomo, 1; “The human soul, as Cicero states, is covered by the most obscure veils of simulation; when you think that the eyes, the forehead, the face as a whole and someone's speech are telling you the truth, that is when they lie at their best. At times you can see, under the face 
If the reference to simulation does suggest connections with theatre and with the wider reflection on the topic that (as shown by seminal studies such as Jon Snyder's) is peculiar to late Renaissance culture and the Baroque, the relation between physiognomy and literature-drama in particular-becomes all the more evident when we consider the characterization of human types. ${ }^{12}$

In Della Porta's treatises on physiognomy, descriptions of famous figures from the literary tradition create a veritable gallery of portraits aimed at supporting detailed analysis of bodily signs and human traits. In this respect, the Coelestis Physiognomonia of 1603 is characterized by a model structure. Each chapter focuses on behavioural and physical traits linked to specific constellations and planets; basically, a combination of physiognomy and astrology. Explanations include examples taken from the past, both historical and mythical. For instance, the characteristics of saturnine people-specifically, their inclination for ailments caused by black bile and epilepsy-are first exemplified by Hercules, Lysander Lacedaemonius, Ajax, and Bellerophon, a list of mythological heroes that Della Porta found in Aristotle's Problemata. ${ }^{13}$

of a kind man, as Seneca maintains, a cruel soul, crueler than the cruel beasts. For this reason-and in order not to be deceived-Socrates wished that a window would be opened on the chest of men, so as to avoid being deceived by a two-faced heart, and let people grasp intention, thoughts, truths and lies of their interlocutors. Physiognomy satisfies Socrates' desire. [...] In fact, from the bodily signs of men, this science reveals their intentions and behaviours, as if it were able to penetrate the hidden abysses of the heart. This is a divine gift that lets men know whom to be acquainted with and whom to escape from."

12. On the relevance of simulation to late Renaissance and Baroque culture, see Francis Bacon's Essays (first edition, London: Humfrey Hooper, 1597), particularly "Of simulation and dissimulation," and Torquato Accetto's Della dissimulazione onesta of 1641, now available in the modern edition Della dissimulazione onesta, ed. Salvatore S. Nigro (Turin: Einaudi, 1997). A wide-ranging discussion of the topic is found in Jon R. Snyder, Dissimulation and the Culture of Secrecy in Early Modern Europe (Oakland: University of California Press, 2009). I wish to thank one of the anonymous reviewers for the insightful comments on this aspect. For a thoughtful insight into the characterization of human types in late Renaissance literature, see Sergio Zatti, "Torquato Tasso: Epic in the Age of Dissimulation," in Zatti, The Quest for Epic (Toronto: University of Toronto Press, 2006), 195-216.

13. "Et Aristoteles, Problematum libro, claros homines atra bile laborare dixit et epilepsiae esse obnoxios: Herculem ab eo morbo vexatum fuisse, ob id epilepsiam herculeum morbum dixerint, ita Lysandrum Lacedaemonicum, Ajacem et Bellerophontem: hic enim solitarius avia prosequebatur loca, ille insania correptus seipsum interemit" (Della Porta, Coelestis physiognomonia, 30); "Aristotle in the book of Problems said that great men did suffer from black bile, thus being epileptic. Since Hercules suffered from that disease, they called epilepsy Hercules's disease. Likewise Lysander Lacedaemonius, Ajax, and Bellerophon. The latter, being a solitary, used to spend time in lonely places; the former, being mad, 
In his catalogue, though, classical mythology is combined with historiography. Portraits of heroes are seamlessly juxtaposed to portraits of historical figures, as is clear in the chapter devoted to the physical and moral traits of the Jovial person: these are embodied at their best by Jupiter, whose description is followed by those of Priamus and Charlemagne, allegedly "real" incarnations of the ideal type. ${ }^{14}$

In the treatise Della fisionomia dell'uomo, the use of literary sources is not limited to epic and historiography. ${ }^{15}$ The author turns here often to drama: in fact, along with those to illustrious men, references include a significant number of characters taken from Latin comedy and, less frequently, from Greek tragedy: Plautus is quoted at least twenty times, while Greek authors such as Euripides and Sophocles only a few times, respectively five and two. ${ }^{16} \mathrm{~A}$ similar use of Plautus should not surprise us, since the Latin playwright is possibly the most influential model for Della Porta's dramas. ${ }^{17}$ The imitation of Plautus stemmed from the Neapolitan's long acquaintance with the Roman author, indirectly witnessed by a now lost Italian translation of the Plautine corpus that-according to biographers-Della Porta did not have a chance to publish. Despite the uncertainty of such information (backed up by the mention of a

killed himself.' For Della Porta's reference, see Aristotle, Problems, trans. W. S. Hett (Cambridge, MA: Harvard University Press, 1957), 30, 953a, 15-23.

14. "Regiam Iovis formam et mores praetulit Troianorum rex Priamus [...] Fuit suavis, moratus et omnibus praeditus virtutibus. Non absimilem sortitus est formam Magnus Carolus, rex Francorum, albo enim et roseo vultu, fulvis magnisque oculis, succincta coma, fronte et ore adeo generoso et venerabili, ut vere augustae maiestatis specimen prae se ferret ut, qui illud contemplarent, quasi divinum venerarentur" (Della Porta, Coelestis physiognomonia, 32); "King Priam of Troy did have the royal aspect that was peculiar to Jupiter. [... He was kind and rich in all virtues. A similar shape was that of Charlemagne, king of France, whose face was white and red, his eyes large and bright, his hair short, his face and forehead so venerable that they showed his royal majesty, for which he was venerated." Della Porta is here combining a poetical source for the description of Priamus (Dares Phrygius, quoted via Cornelius Nepos) with a historiographical one for the description of Charlemagne (Einhard's Vita Karoli Magni).

15. We will consider the Italian translation of the six-book version (Della Porta, Della fisionomia dell'uomo). For a detailed introduction to the work and a discussion of the different versions, see Della Porta, De humana physiognomonia, xi-lxi.

16. Della Porta refers to Greek playwright Eupolis as well, but this is a mistaken quotation that the author found in Galen: Della Porta, Della fisionomia dell'uomo, 6.3, 564.

17. Sirri, Sul teatro del Cinquecento, 377. 
similarly lost treatise De arte componendi comoedias), what matters is that the natural philosopher's interest in drama-specifically in Latin comedy-went far beyond occasional circumstances. ${ }^{18}$

With regard to the function of references to drama in the treatise, it is worth stressing that Della Porta uses Latin comedy when he wants to support his statements through examples that claim to represent the "real" world. More precisely, the author refers to Plautus in two ways, either quoting specific passages from the text or simply mentioning characters from the comedies. For instance, within the discussion of humours and temperaments, Della Porta illustrates the hot-tempered complexion ("umore sanguigno"), by quoting from Plautus's Bacchides:

Lido pedante si rammarica, appresso Plauto, che, essendo vecchio, era senza sangue; e perciò non aver forza veruna; e Pistoclero giovane suo scolare per lo molto sangue era più gagliardo, e non lo potea castigare: "Il mio scolare è pien di molto sangue / Castiga me, che ne son quasi estinto." 19

More frequently, references to Plautus are less circumstantiated and are primarily concerned with allusions to characters and their physical traits. For example, when Della Porta discusses the physical characteristics of human faces, the exemplification of slim faces evokes the portrait of Leonidas in Asinaria and that of Philocrates in Captivi as a complement to the definitions found in prestigious physiognomical auctoritates such as Aristotle, Polemo, and Adamantius:

18. Romei and Zaccaria, 179. For Della Porta's "complete familiarity" with Plautus, see Clubb, 117, where the scholar also suggests that Della Porta's treatment of physiognomy in La Trappolaria might be influenced by Ludovico Ariosto's Cassaria. I wish to thank Stefano Jossa for bringing this detail to my attention.

19. Della Porta, Della fisionomia dell'uomo, 1.9, 55; "In Plautus, Lido, the pedant, complains about his old age and lack of blood, which both decrease his physical strength; Pistoclerus, his young pupil, because of the abundance of blood, was much stronger and difficult to tame. 'My pupil has much blood in his body, / Punish me, who am almost dead." For the original passage, see Plautus, Amphitryon, The Comedy of Asses, The Pot of Gold, The Two Bacchises, The Captives, ed. and trans. W. de Melo (Cambridge, MA.: Harvard University Press, 2011), 171-72. 
Chi ha la faccia macra è circonspetto, e molto avveduto nell'opere sue, e di sottile intelletto. Così Aristotele ad Alessandro. E nella Fisonomia: quei che hanno la faccia macra, sono solleciti. [...] Polemone et Adamanzio: la faccia picciola è dello studioso et infidele [...] Plauto nella sua Asinaria fa il suo Leonida, che è sollecito e astuto di guancie macre. E Filocrate, che scappò dalle catene per l'astuzia sua, fu pur di faccia macra. ${ }^{20}$

As this example shows, the author considers the Plautine corpus as a catalogue of standardized characters in which the relation between bodily signs and behaviours seems to confirm the connection between the external appearance of a person and the inner nature of his soul. Drama thus enters the realm of physiognomy in its classical meaning of speculum vitae humanae; by reproducing on stage what happens in real life, drama discloses both its pedagogical and epistemological potential.

\section{Physiognomy into drama}

Since Plautus's gallery of characters is singled out by Della Porta in the treatise Della fisionomia dell'huomo, one might wonder whether the relation between drama and physiognomy is valid the other way around: did the author's physiognomic expertise somehow affect the construction of characters in the plays? As is well known, since Renaissance comedy imitates closely forms of classical theatre, characters in sixteenth-century comic theatre tend to replicate features of their ancestors', at least in terms of roles and narrative functions. Within such a frame-which privileges the literary dimension of drama-the creative freedom of the playwright is, in a way, limited. Yet, it is in this limited space for innovation and in the ability to reshape a long-established tradition that Della Porta's inventiveness stands out. ${ }^{21}$

20. Della Porta, Della fisionomia dell'uomo, 2.10, 175; “Those with slim faces are cautious, thoughtful in their actions, and of subtle intellect; so Aristotle says to Alexander. And in the Physiognomy: those with slim faces are prompt. [...] Polemo and Adamantius: small faces are typical of studious and unfaithful people [...] Plautus, in his Asinaria, portrays Loenidas, who is prompt and sly, as someone with slim cheeks. And Philocrates, who escaped from his prison thanks to his shrewdness, has also slim cheeks." 21. While we will refer later in this section to some aspects of Della Porta's plays that relate to the materiality of the staging, the lack of information about actual performances of the comedies prevents us from making here substantial remarks about the "theatricality" of the playwright's corpus. Our 
Indeed, physiognomy and drama meet when the determinism that informs the classical inventory of comic characters (young lovers, old fathers, boastful warriors, shrewd servants, procurers, etc.) is reinterpreted in light of the laws that govern the relations between soul and body. If Della Porta carefully reminds us in his treatises that free will is not weakened by the interdependence of soul and body, physiognomic determinism becomes in the plays a multifaceted source of comedy, especially where the rhetorical strategies behind the construction of characters are concerned. In fact, references to physiognomy prove particularly important to the elaboration of comic plots, as suggested by a variety of dramatic devices that can be grouped in four categories: (1) descriptions of characters; (2) judgments based on physical traits; (3) zoomorphism; (4) pathognomy.

(1) Consistently with most of the dramatic tradition of the time, Della Porta's theatre has a strong narrative component, which means that a significant amount of action is narrated instead of being staged. Therefore, the first textual space that offers evidence of the playwright's physiognomic expertise is the description of characters, often aimed at introducing their features when they are absent. The use of hypotyposis is entirely based on the author's ability to manipulate words in order to let the audience visualize the characters even when they are not on stage. As a matter of fact, Della Porta proves a veritable virtuoso in the way in which he uses words in order to shape vivid and memorable portraits.

A very good example of this-all the more interesting given its metatheatrical implications-is offered by the prologue to the comedy L'Olimpia (1589), where the description of the play as a beautiful young woman deploys all the commonplaces of a longstanding literary tradition..$^{22}$ It is nonetheless in the grotesque overturning of the classicist trope of the descriptio puellae that

analysis will thus focus on the intersections of Della Porta's physiognomical discourse and the author's dramatic production by looking primarily at the literary dimension of the text (which, as we shall see, was also Della Porta's primary preoccupation, consistently with the tradition of the commedia erudita or regolare that blossomed throughout the sixteenth century). Yet, a thorough study aimed at checking whether or not these intersections affect the theatrical quality of the texts would be of great interest. I wish to thank one of the anonymous reviewers for highlighting the importance of this matter.

22. Della Porta, Teatro, 2, 11-12. 
Della Porta's physiognomic knowledge stands out. ${ }^{23}$ This happens, for instance, in the comedy La turca (1606), where Argentoro's description of his own wife, previously kidnapped by Turkish pirates, reshapes the physiognomic syllogism (according to which human beings share the behavioural qualities of the animals they resemble) in terms of comic debasement: ${ }^{24}$

\begin{abstract}
ARGENTORO: [...] Ella aveva una fisiochionomia piutosto di vacca che di donna; ma era asciutta, che pareva il ritratto della peste e della carestia: gli occhi guerci, spaventosi, usciti fuori, che mirando te pareva che mirasse altrove; il naso tanto lungo che, volendo uscir fuori, la punta era già in piazza e la persona ancora in casa; il mostaccio di babuino, la carne dura e nera come storno. Quando caminava per le strade, era la civetta de' putti. E quando, doppo le fatiche del giorno, veniva a casa per riposarmi, allora cominciavano i guai, che ponendo la lingua in volta, straccava le orecchie, ed erano tante le bave che li colavano dalla bocca, ch'era bisogno porle il bavaruolo, come si fa a' putti; senza l'ingiurie, le bestemmie e i visi torti, talché la tavola mi era il mortorio. ${ }^{25}$
\end{abstract}

The portrait of Argentoro's wife is clearly informed by the fascination with the grotesque that was peculiar to the figurative and literary culture of the socalled "counter-Renaissance." ${ }^{26}$ If the description is undoubtedly influenced

23. On the trope of the descriptio puellae, see the canonical studies by Giovanni Pozzi, "Il ritratto della donna nella poesia d'inizio Cinquecento e la pittura di Giorgione," and "Nota additiva alla descriptio puellae," in Pozzi, Sull'orlo del "visibile parlare" (Milan: Adelphi, 1993), 145-72,173-84.

24. For a definition of sillogismo fisiognomico, see Della Porta, Della fisionomia dell'uomo, 96-98.

25. Della Porta, Teatro, 3, 243; "She had the physiognomy of a cow rather than of a woman; but she was slim, looking like the portrait of plague and famine: her eyes, crossed, fearful, and sticking out, while looking at you, were directed elsewhere; her nose was so long that, when she got out of the house, the point was already in the square while the rest of the body was still home; she had mustaches like a baboon and her flesh was hard and black as that of a starling. When she walked down the street, kids made fun of her. And when after a long day of work I got back home, there my troubles began; her tongue and ears were revolting and she had tons of drool pouring from her mouth so that she needed to wear a bib, as is the case with babies; to say nothing of the insults and curses that made my dinner a veritable funeral."

26. For the notion of counter-Renaissance, although controversial and widely debated, see Hiram Haydn, The Counter-Renaissance (New York: Grove Press, 1960); Eugenio Battisti, L'antirinascimento (Milan: Garzanti, 1989). 
by the classical topos of the ugly old lady, what distinguishes Della Porta's re-enactment of the image is the exaggeration of disgusting details, which stems from the author's interest in the observation of the human body in all its manifestations. Through the verbal virtuosity deployed in the passage, the markedly anti-classicist quest for a conscious aesthetics of ugliness reveals its strong comic potential.

(2) Whereas the physical description of absent characters is primarily a fact of verbal vividness, there are many instances in which characters talking to each other elaborate judgments based on what their interlocutors look like. Someone's behaviour, for example, can be criticized through allusions to his or her aspect (la cera), which is supposed to reveal something about his or her inner nature. Situations of this kind stress the idea that, by looking at someone's appearance, it is indeed possible to form a judgment (or even to recognize an identity). One might think of Fagone's address to his interlocutor Lucrino in La trappolaria (1596): "Certo che voi sete quel che cerco. Vi conosco alla ciera, vi veggio nel viso i trionfi del vostro mestiero," where the face of the ruffiano is said to be eloquent enough to reveal his shrewd nature. ${ }^{27}$ If the word ciera is a generic allusion to the face of a character, in other cases references to the science of physiognomy are more explicit, though ironic, as happens with the astrologer Albumazar, the title role of the comedy L'Astrologo (1606). The fake magician - a favourite character in Renaissance comedy - is very familiar with physiognomy, as suggested by two key passages in L'Astrologo that are worth discussing here. At the beginning of act 1, Albumazar reads through his three servants' faces and articulates his judgment based on the laws (literally, on the signs) of physiognomy:

\begin{abstract}
ALBUMAZAR: [...] se non mentono i segni della fisonomia che ne' vostri fregiati visi si veggono, come uomini della prima bussola ne ho fermo proposito che sete per ascendere a gradi più alti e far più gran salti e avere carichi sulle spalle i maggiori che sian al mondo $[\ldots] .{ }^{28}$
\end{abstract}

\title{
27. Della Porta, Teatro, 2, 275.
}

28. Della Porta, Teatro, 3, 330; "If the signs of your physiognomy that I see on your faces do not lie, I am sure that you are men destined to big things and ready to bring on your shoulders the heaviest charges in the world." 
Later in the same act, the astrologer elaborates an ironic judgment of the servant Cricca by turning to the same method:

CRICCA: Astrologo, di che ciera ti paro io?

ALBUMAZAR: Ho visto mille appiccati in vita mia, ma non ho veduto la più maladetta e scomunicata fisonomia e ciera della tua; e se tu fossi un po' più alto da terra, direi che sei stato appiccato già. ${ }^{29}$

As these examples show, the charlatan's simplistic use of physiognomy poses ironic questions about the status of the discipline. Of course, Della Porta does not conceal his satirical intention. Satire is in fact a veritable leitmotif in the ways in which the playwright addresses - on the theatrical stage-controversial disciplines such as magic, astrology, and physiognomy itself. It goes without saying that such disciplines are not criticized per se, but as something that can be easily turned into the instrument of crooks to the detriment of gullible people.

(3) Another facet of Della Porta's physiognomic expertise that translates into his comic dramas is the judgment of people based on their resemblance to animals. Della Porta uses zoomorphism, which is one of the most complex components of physiognomy, in most inventive ways. For sure, the possibility to address comic characters-especially those who belong to lower strata of society and are more often the target of jokes-by alluding to their likeness to animals is very frequent in comic literature. This commonplace, which becomes in Della Porta much more than a trope, offers an invaluable key to understanding the relation between physiognomy and drama.

The easiest and most common example is that of the remarks noting correspondences between zoomorphism and specific behaviours, as per Morfeo's simplistic statement in La Fantesca (1592): "[... ] non vedete che faccia da bufalo? Quella ciera parla e grida che è la maggior bestia del mondo," where the ironic use of physiognomical categories is entailed by the tautological argument based on the pejorative function of the animal metaphor (someone's

29. Della Porta, Teatro, 3.339; "CRICCA: Astrologer, what kind of aspect do you spot on my face? ALBUMAZAR: I have seen thousands of people hanged in my life, but I have never seen such a damned and rotten physiognomy! If you were just a little above the floor, I would say that you have already been hanged!" 
face recalls that of a buffalo, hence he is a boor). ${ }^{30}$ However, as noted above, Della Porta's innovative approach is more evident when the commonplace is overthrown in order to foster comic effects. This concerns, in the first place, the characterization of stock roles such as the boastful Spanish captain-one of the most hilarious among Della Porta's recurrent characters, basically an update of the Plautine miles gloriosus. In the comedy L'Olimpia (1589), Captain Trasilogo overturns the physiognomic syllogism according to which there is a connection between the aspect of heroic men and specific animals such as horses. Paradoxically, one of Trasilogo's horses looks so much like him that the animal himself deserves to be named "Captain."

TRASILOGO: Ancora: che i cavalli fresoni, ginetti di Spagna e quelli del Regno sieno stregiati e forniti di tutto punto, e fra gli altri lo stornello che si chiama il Capitano, che s'assomiglia tutto a me d'animo, di forza e di gagliardia. ${ }^{31}$

The similarity between men and animals is also at the core of the comedy $\mathrm{La}$ chiappinaria (1609), where the young lover Albinio, taking advantage from the presence in town of a frightening bear, disguises himself as a bear so as to gain access to his lover's house more easily. The instructions given by the servant Truffa to his master are very detailed, ranging from the fabrication of the costume to the ways in which Albinio should imitate the movements of a bear-to say nothing of the most ironic mention of the crucial help coming from nighttime darkness, which will make up for any flaws in the performance:

TRUFFA: [...] Primieramente bisogna trovare una pelle d'orso, che nelle botteghe di coloro che foderano le vesti di pelli per l'inverno se ne trovano assai $[\ldots]$. Ve ne accomodarem una sovra, che possa chiudersi per tutto con bottoni ed aprirsi da voi stesso quando bisognasse. [...] Come sarete dentro, diffibiate la pelle e ve ne entrerete in camera di Drusilla. [...] La forma dell'orso è più facile a fingersi dall'uomo fra tutti gli animali: ha le braccia che si piegano in dentro come l'uomo, ed avendo voi a caminare coi

30. Della Porta, Teatro, 3.138.

31. Della Porta, Teatro, 2.23; "Also, my horses from Frisia and those from Spain, as well as the ones from the kingdom should be curried and duly prepared, and, among others, the horse that is named Captain, who is the like of myself in braveness, strength and sturdiness." 
piedi e con le mani, piegandosi in dentro, vi porgono molta commodità. [...] Appresso, l'orso è un animale pelosissimo, e quei velli così longhi copriranno le cuciture e i bottoni, che non lasciaranno conoscere dove siano. [...] L'orso poi è un animal grossolano, senza forma, e questo coprirà ogni difetto che potesse mostrare la pelle, che dentro vi fosse un uomo. [...] Poi la notte coprirà ogni mancamento. ${ }^{32}$

\title{
Truffa's instructions for Albinio's costume prove all the more interesting if we recall what Della Porta says about the nature of bears in the treatise Della fisionomia dell'uomo. There, the bear is listed and described among the animals that, having a negative characterization, are discussed in relation to the beastly and malicious man ("della figura del bestiale malitioso"):
}

\begin{abstract}
Or opporremo i segni del malizioso bestiale, e lo rassomigliaremo a gli orsi o a quelli animali che si trovano più crudeli, e peggiori; ché gli orsi sono bestiali et astuti, crudeli, perfidi e fraudolenti, et avanzano di ferità ogni bestia, come dice Filostrato, e Ovidio: "Che altro è l'orso che un disutil peso / Ferocità d'una ben pazza mente.” È tanto maligno, e pieno di fraude, che fatto domestico e mansueto quanto si voglia, subito ritorna alla natura primiera, onde gli huomini spesso ingannati da questa mansuetudine, hanno isperimentato da loro assai miserabili casi. ${ }^{33}$
\end{abstract}

32. Della Porta, Teatro, 4.25-26; "First of all, we need to find a bearskin, one of those that are easy to find in the tanners'. [...] We will cover you with one, which you will be able to close and open yourself with buttons. [...] When you will be inside the home, untie the bearskin and enter Drusilla's bedroom. [...] The bear is the easiest animal to mimic for men: it has arms that fold as men do, and-since you will need to walk with both hands and feet, this feature will be of help [...] Furthermore, bears are very hairy, and the hair will hide seams and buttons. [...] Bears are also coarse animals, without a proper shape, and this will make up for any defects that the bearskin might have, thus avoiding to show that a man is inside. [...] The night will then conceal any other flaws."

33. Della Porta, Della fisionomia dell'huomo, 549; "Now we will outline the signs of the malicious and bestial man, whom we will compare to bears and other cruel animals. Bears are indeed bestial, shrewd, cruel, sly and false; their perfidy surpasses that of any other animal, as is said by Philostratus, and Ovid: 'What is a bear, if not a useless load, anger of a mad mind.' Bears are evil and cunning; even when they are domesticated, they quickly go back to their original nature, as many people-often deceived by such docility-have experienced in miserable events." For a fascinating account of the meanings that the image of the bear embodied throughout the ages, see Michel Pastoureau, The Bear: History of a Fallen King (Cambridge, MA: Harvard University Press, 2011). 
The text is illustrated by an image that represents the uomo bestiale in a way that is meant to recall the figure of a beast, suggesting gestures easily translatable on stage. ${ }^{34}$ The woodcut evokes the mimicking movements of the actors of the commedia dell'arte and invites us to reflect not only on the relation between physiognomy and drama, but also and foremost on the relation between physiognomy and dramatic practice, a relation that Della Porta himself suggested in the discussion of the human body as an imago agens in his Ars reminiscendi. ${ }^{35}$ In fact, as professional acting companies flourished across Italy and beyond, the combination of verbal communication and body language became one of the theatre's most important components. The body tends to prevail over words: Della Porta, who never gave up conceiving of theatre as primarily written and did not approve of the excessive freedom of improvised drama, aimed to find a compromise between his literary taste for verbal excess and the expressive potential of gestures that only on stage would find its complete realization.

(4) In a way, physiognomy provides the playwright with a basic catalogue of human types ready for the stage. Along with a variety of characters based on the model outlined by Aristotle's discussion of ethos in book 2 of his Rhetoric, the fifth book of Della Porta's Fisionomia dell'uomo dwells on icastic illustrations of human behaviours and gestures that recall those of actors. ${ }^{36}$ As such, physiognomy acquires on stage a vitality that is foreign to its traditional taxonomy, primarily based on immobile figures, where natural signs are not affected by emotionally driven alterations. Of course, Della Porta's plays are far from identifying psychologically consistent characters, a feature that will be one of the aims of modern drama. Yet Della Porta's is a veritable theatre of passions and affections, which - while devoid of insights into human nature in modern psychological terms-focuses on the combinatory display of the ways in which stock characters embody, manage, and fake emotions.

In fact, if references to the bodily signs of characters are numerous in Della Porta's comedies, the playwright gives even more attention to those "transient" signs of the body that witness behavioural alterations or faked

34. It is worth remarking that the same image was also used to illustrate the figure of the lustful man: see Della Porta, Della fisionomia dell'huomo, 522.

35. See, on this topic, Bolzoni, "Teatro, pittura e fisiognomica," and "Retorica, teatro, iconologia."

36. For the Aristotelian discussion of characters, see Aristotle, Rhetoric, 2.12-14; in Aristotle, Art of Rhetoric, trans. J. H. Freese (Cambridge, MA: Harvard University Press, 1926). 
affections ("[gli] accidenti che trasmutano i segni,"). ${ }^{37}$ As implied by Della Porta's statements about simulation in the treatise Della fisionomia dell'uomo, it is fair to say that physiognomy finds its more compelling application when it turns into "pathognomy"; the main focus is no more on an allegedly stable physis (nature), but on an ever changing pathos (passion), whose expression finds its most complete and evident embodiment in the actor's work. Among the many examples available from Della Porta's comic corpus, Omone's description of his lover Oriana in the comedy Il moro (1607) is particularly telling:

OMONE: [...] Ma vo' osservar i suoi andamenti, ed i moti degli occhi e del volto, per conoscer li effetti dell'anima sua. Vedo che piange, e teme e nasconde i singhiozzi; il volto cambia mille colori, non sa star ferma. Mostra allegrezza in vedermi, ma mostra con la presenza quello che vieta il cuore. ${ }^{38}$

Movements of the eyes and facial reactions reveal the lover's suffering, basically a silent language to communicate emotions. However, the sincere expression of the soul's turmoil is only one of the possibilities entailed by the staging of passions; in fact, Della Porta's plays often refer to the characters' ability to turn to a well-codified pathognomy in order to simulate, thus appearing different from what they actually are.

\section{Conclusion}

The theatrical potential of simulation obviously implies an ironic judgment on the laws of physiognomy, the epistemological value of which is completely frustrated when brought on stage (the same ironic take informed, as we have seen, the characterization of the astrologer in Della Porta's L'Astrologo). Albinio's bearlike costume is, from this point of view, an extreme example of such a process, for it completely overturns the zoomorphic principle that lies at the foundations of the physiognomic discourse. Yet both disguise and character

37. Della Porta, Della fisionomia dell'huomo, 96.

38. Della Porta, Teatro, 3.421-422; "I want to observe her behaviour, as well as the movements of her eyes and face, in order to know the intentions of her soul. I see that she cries and fears hiding her sighs; her face keeps changing colour, she can't stay put. She shows happiness in seeing me; with her body and gesture, she shows what her heart forbids." 
mix-ups count among the most typical devices used by Della Porta in his comedies, where misunderstandings are primarily based on the overthrowing of the physiognomic code. The playwright stages paradoxical situations in which the character's identity is often cancelled. The artifice of simulation reaches extraordinary levels of complication, thus challenging the idea-often debated within the plays themselves-of the alleged correspondence between eyes, face, and soul. In fact, it is quite easy to find characters arguing that it is impossible to grasp the essential traits of a person from his or her bodily signs. Likewise, it is common to find a character who is ready to acquire any identity, even the one that other interlocutors insist on attributing to him.

The various examples discussed in this article merge into a paradox: on the one hand, Della Porta's physiognomic expertise undoubtedly plays an important role in the rhetorical strategy that informs the construction of characters in the plays (particularly in terms of verbal exaggeration); on the other hand, the theatrical code of fiction and simulation, based on the actor's ability to perform continuous metamorphoses, questions the risk of determinism entailed by the very notion of physiognomy. Just think of Panurgo in La Fantesca: a typical servo furbo, whose name recalls Rabelais's Panurge, he knows how to simulate and, if required by the situation, identify himself with someone else. Only at the end of the play he reveals that he is not a servant but an impoverished gentleman who had been pretending to be a servant in order to recover his status.

The echo of Della Porta's physiognomy resounds in the plays, thus confirming the complexity of the author's profile. Theatre is a lens through which to observe the world and, above all, men and women caught in the neverending game of human relations. Drama is an extraordinary kaleidoscope that acknowledges the power of simulation without giving up the utopian project of a truthful knowledge of human nature. Such a paradox should not surprise us at all, for Della Porta himself perceives the world as hanging in the balance between being and appearance. As recalled by his contemporary William Shakespeare in Macbeth, “There's no art / To find the mind's construction in the face." ${ }^{39}$

39. William Shakespeare, Macbeth, 1.4.11-12. I quote from The Complete Works of Shakespeare, ed. David Bevington (Glenview, IL: Scott, Foresman and Company, 1980), 1223. 
